\title{
DECA Regimen
}

National Cancer Institute

\section{Source}

National Cancer Institute. DECA Regimen. NCI Thesaurus. Code C67190.

A regimen consisting of dexamethasone, etoposide, cytarabine, used for the treatment of recurrent childhood Hodgkin lymphoma. 